\title{
BIOLOGIA CELULAR, EDUCAÇÃO ANTIRRACISTA E CURRÍCULO DECOLONIAL: experiências didáticas inovadoras na formação inicial no curso de ciências biológicas
}

\author{
José Antônio Novaes da Silva (Baruty)'
}

\section{RESUMO}

O presente artigo apresenta experiências didáticas realizadas no campo da Biologia Celular, em específico da Citologia, visando cumprir orientações da Lei de Diretrizes e Bases da Educação Brasileira (1996), que inseriu mudanças nos curńculos escolares após a promulgação da Lei n 10.639/2003 - Educação das Relações Étnico-Raciais, História da África e da Cultura Afro-Brasileira. Nesse sentido, na formação inicial - primeiro semestre - de discentes do curso de Ciências Biológicas da Universidade Federal da Paraíba, foi utilizada uma metodologia com o propósito de aplicar de forma inovadora a referida Lei. Como resultado, tivemos a apresentação de 34 trabalhos por 120 discentes no formato de painel que foram apresentados à comunidade acadêmica, relacionados aos seguintes temas: preparação tecidual, Saúde da População Negra, personalidades negras e estruturas celulares. As atividades foram norteadas pelas perspectivas da Educação Antirracista e Colonialidade/Decolonialidade que propõem a descolonização dos currículos, buscando a superação do eurocentrismo que ainda está fortemente presente no sistema educacional brasileiro.

Palavras-chave: Biologia celular. Educação antirracista. Inovação curricular.

\section{CELLULAR BIOLOGY, ANTI-RACIST EDUCATION AND DECOLONIAL CURRICULUM: innovative teaching experiences in initial training in biological sciences} course

\begin{abstract}
This article presents didactic experiments carried out in the field of Cellular Biology, specifically in Cytology, aiming to comply with the procedures of the Brazilian

\footnotetext{
1 Doutor em Bioquímica pela Universidade Estadual de São Paulo. Pós-doutor pelo Centro de Estudos Sociais da Universidade de Coimbra. Professor Titular da Universidade Federal da Paraíba (UFPB), João Pessoa, Paraíba, Brasil. Coordenador do Núcleo de Estudos AfroBrasileiros e Indígenas da UFPB. Orcid ID: https://orcid.org/0000-0002-8418-2504. Email: baruty@gmail.com.

2 Agradeço à Professora Dra Solange Rocha, do Departamento de História da UFPB e integrante do NEABI/UFPB, pela leitura crítica do manuscrito bem como pelas valiosas sugestões.

3 À Senhorita Dani, secretária da revista, que muito atenciosamente acolheu meu pedido de ajuda em relação ao site da revista abrindo para mim um canal de comunicação, sem o qual o presente artigo não teria sido publicado.
} 
Education Guidelines and Bases Law (1996), which introduced changes in school curricula after the enactment of Law 10.639 / 2003 - Education of Ethnic-Racial Relations, African History and Afro-Brazilian Culture. In this sense, in the first semester in students' initial training of the Biological Sciences course of the Federal University of Paraíba, a methodology was used with the purpose of applying this Law in an innovative way. As a result, a total of 34 papers were presented by 120 students in panel format and shown to the academic community. They related to the following topics: tissue preparation, Black Population Health, black personalities and cellular structures. The activities were guided by the perspectives of Anti-racist Education and Coloniality/Decoloniality that propose the decolonization of curricula, seeking to overcome Eurocentrism, which is still strongly present within the Brazilian educational system.

Keywords: Cellular biology. Anti-racist education. Curricular innovation.

\section{BIOLOGÍA CELULAR, EDUCACIÓN ANTIRRACISTA Y CURRÍCULO DECOLONIAL:}

\section{experiencias didacticas innovadoras en la formación inicial en la carrera de}

\section{ciencias biológicas}

\section{RESUMEN}

El presente artículo presenta experiencias didácticas realizadas en el campo de la Biología Celular, específicamente la Citología, con el objetivo de cumplir las pautas de la Ley de Directrizes y Bases de la Educación Brasileña (1996), que introdujo cambios en los currículos escolares después de la promulgación de la Ley $n^{\circ}$ 10.639/2003 - Educación de las Relaciones Étnico-Raciales, Historia de África y de la Cultura Afrobrasileña. En este sentido, en la formación inicial - primer semestre - de estudiantes de la carrera de Ciencias Biológicas de la Universidad Federal de Paraiba, se optó por una metodologia innovadora con el propósito de aplicar dicha ley. Como resultado, 120 estudiantes presentaron para la comunidad académica paneles de los siguientes temas: Preparación de Tejido, Salud de la Población Negra, Personalidades Negras y Estructuras Celulares. Las actividades se han orientado hacia la Educación Antirracista y la Colonialidad/Decolonialidad, que proponen la descolonización de los currículuns buscando superar el eurocentrismo que todavía tiene relevancia en el sistema educativo brasileño.

Palabras clave: Biología celular. Educación antirracista. Innovación curricular.

\section{INTRODUÇÃO}

No ano de 2003, o artigo 26 da Lei de Diretrizes e Bases da Educação (LDB) foi alterado com a promulgação da Lei no 10.639, a qual assevera que "Nos estabelecimentos de ensino fundamental e médio, oficiais e 
particulares, tornou-se obrigatório o ensino sobre Educação das Relações Étnico-Raciais e História da África e Cultura Afro-Brasileira2".

Diante desta alteração com inclusão no campo educacional brasileiro, conquistada pelo Movimento Social Negro, como poderia a Biologia, mais especificamente a área de Biologia Celular (Citologia), cumprir seu papel educacional de forma a colocar em prática o referido marco legal? O questionamento é válido, pois a Biologia Celular, enquanto área das Ciências Naturais, também pode contribuir para a construção da cidadania, bem como para a Educação das Relações Étnico-Raciais.

No sistema de ensino formal, temos as Ciências Naturais (Ciências da Natureza), ou apenas Ciências, que, em nível do ensino fundamental, englobam os campos do conhecimento da Biologia, Física, e Química (MARCONDES, 2018). Tais áreas, que no ensino médio, tornam-se mais complexas desdobrando-se cada uma em subáreas dentro de seus campos específicos, de acordo com as Orientações e Ações para a Educação das Relações Étnico-Raciais (BRASIL, 2006), podem colaborar para a descolonização de conhecimentos que afirmam a existência de grupos naturalmente inferiorizados. Assim, a Biologia passa a ser estudada na Citologia, Embriologia, Ecologia, Genética, Botânica, Fisiologia, Zoologia, dentre outras áreas. Das várias subáreas, poucas são divulgadas pela mídia e mesmo estas são mostradas de forma independente, fragmentadas como se isoladas estivessem de um campo maior que as abarcassem e até de um processo de discursividade.

O campo das Ciências Naturais vem dando sinais de mudanças com relação à Lei no 10.639/2003. Nesse sentido, Verrangia; Silva (2010) elaboraram um levantamento de estudos recentes articulando o ensino das Ciências Naturais. Silva (2017), por seu turno, publicou, no Dossiê Temático "Por uma produção de Ciência Negra: experiências nos currículos de 
Química, Física, Matemática, Biologia e Tecnologias3", artigo no qual discute alguns desdobramentos ocorridos a partir desta lei e propõe temas, que, de forma interdisciplinar, podem contribuir para a atuação de docentes de Ciências e Biologia para que desenvolvam um novo currículo considerando este marco legal em suas aulas. Concordamos com Morais; Santos (2019, p. 72), os quais afirmam que "a ciência da natureza não deve se posicionar fora das fronteiras da missão solidária, a saber: a busca da desalienação, da descolonização, da diversidade, da equidade, da emancipação das identidades racializadas".

Isto porque nos primeiros quarenta anos do século oitocentos, a Biologia se estabeleceu como uma ruptura com as linhas de pensamento da época (DUARTE, 2010), pois na "passagem do século XVII para o XVIII, a História Natural, que até então era constituída quase que inteiramente por taxonomistas, mudou de mera descrição de fatos a um conjunto de disciplinas científicas com seus próprios métodos, distintos das Ciências Físicas" (POLISELI; OLIVEIRA; CHRISTOFFERSEN, 2013, p. 108). Nessa época, 1840, a denominação da nova área do conhecimento se desenvolveu a partir da Embriologia, Citologia, Fisiologia, Evolução e da Genética (MAYR, 2005), oferecendo um "extraordinário desenvolvimento teórico, com a elaboração de leis, bem como de conceitos" (ROSA, 2010, p. 261).

A Biologia inaugura uma nova forma de se ver a vida e não somente os seres vivos (PORTOCARRERO, 2000), a qual difere, radicalmente, da História Natural, que se mostra voltada para o campo do visível, do detalhamento e da descrição minuciosa (DUARTE, 2010), porém ambas compartilham sua utilização por correntes políticas, uma vez que a História Natural contribuiu para a edificação dos grandes impérios modernos e a Biologia esteve a serviço de projetos nacionalistas (DUARTE, 2010).

Durante todo o século XX, a Biologia se firmou tanto em práticas científicas quanto em complexas relações sociais, como um campo

\footnotetext{
3 Lei no 10.639/2003 Disponível em:

<http://abpnrevista.org.br/revista/index.php/revistaabpn 1/issue/view/22>. Acesso em $14 \mathrm{dez}$ 2019.
} 
específico que mantém íntimo vínculo e sistematizações com a vida política e cultural (DUARTE, 2010): a "biologização da vida, que acarretou a naturalização das diferenças" (LOBO, 2008, p. 197), levando à aceitação da inferioridade de pessoas negras e de mestiços/as. Um dos defensores dessa mentalidade era João do Norte $(1929$, p. 4) para quem o cruzamento entre raças, como a branca e a negra, gera um povo "fraco, feio, inferior aos indivíduos puros que o formaram", havendo ainda a crença de que "todas as qualidades físicas e psíquicas, todas as combinações que nós chamaríamos de caráter do ser humano" são determinadas no momento da fecundação (MJOEN, 1931, p. 6), ou seja, o comportamento humano seria celular e determinado pela fusão do óvulo com o espermatozoide. 0 médico sergipano Manoel Bomfim (1868 - 1932) contrapunha-se a este processo de naturalização e afirmava não haver comprovação de que entre mestiços/as houvesse "degenerado de caráter, relativamente às qualidades essenciais das raças progenitoras. Os defeitos e virtudes que possuem vêm da herança que sobre eles pesa, da educação recebida e da adaptação às condições de vida que Ihes são oferecidas" (BOMFIM, 2008, p. 212), o qual combate o naturalismo imputado à diversidade.

O zoologista Candido Firmino de Mello-Leitão (1886-1948), por exemplo, também articulou a Biologia com a ideologia política vigente em sua época, tendo especificamente produzido textos, os quais, segundo Duarte (2010, p. 125), "traziam interpretações da natureza com base em pressupostos eminentemente políticos e recorriam a argumentos científicos para justificar certas concepções sobre a sociedade". Mello-Leitão (1935, p. 37), num momento político no qual Getúlio Vargas (1882-1954) pregava um sindicalismo subserviente, divulgava em seus escritos que em "todas sociedades [...] domina sempre a mais perfeita disciplina, a ordem mais perfeita, realizando o ideal que ainda buscamos", ou ainda, "Olhando-se mais de perto, porém, as relações entre os seres, observa-se que a natureza é sempre uma grande harmonia, onde a mútua dependência, auxílio, diríamos mesmo a amizade, é regra geral" (MELLO-LEITÃO, 1935, p. 63). 
Décadas depois, por meio da mídia impressa, televisiva e a digital, chegam diferentes campos da Biologia ao grande público. Por exemplo, ao longo dos anos 1980, quando do desenvolvimento do Projeto Genoma Humano, a Biologia molecular invadiu os lares do país. O mesmo tema voltou a circular e a causar polêmica quando da discussão em prol da aprovação ou não das cotas "raciais". Nesse momento, a Revista Veja, em sua edição de junho de 2001, estampou em sua capa "Raça não existe", como se esta categoria fosse entendida como algo natural e válida pelos defensores/as das cotas nas universidades públicas. No campo acadêmico, Pena; Bortolini (2004) problematizaram em seu artigo se: "Pode a genética definir quem deve se beneficiar das cotas universitárias e demais ações afirmativas?". A questão posta tem como resposta um "enfático NÃO" (PENA; BORTOLINI, 2004, p. 46), mesmo com o/a autor/a considerando que a "genética moderna pode oferecer subsídios para as decisões políticas e que o perfil genético da população brasileira certamente deve ser levado em conta em decisões políticas" (PENA; BORTOLINI, 2004, p. 46). O posicionamento político do/a autor/a termina por não ter um significado maior, pois os processos de racismo, preconceito e discriminação, a que a população negra encontrase submetida, não se devem ao perfil hereditário, mas ao racismo estrutural e estruturante das relações sociais e raciais brasileiras.

O sistema escravista que teve mais de três séculos de duração levou a uma profunda exploração econômica, divisão, não só física, mas preponderante de desvalorização e de invisibilidade do/a outro/a, ou seja, a população negra. No que concerne a esta apartação, Santos (2010, p. 2324) nos apresenta a seguinte reflexão:

A divisão é tal que "o outro lado da linha" desaparece e enquanto realidade torna-se inexistente, e é mesmo produzido com inexistente. Inexistência significa não existir sob qualquer forma de ser relevante ou compreensível. Tudo aquilo que é produzido como inexistente é excluído de forma radical porque permanece exterior ao universo que a própria concepção aceite de inclusão considera como sendo - Outro. A característica fundamental do pensamento abissal é a impossibilidade da copresença dos lados da linha. Deste lado da linha só pode prevalecer na medida em que esgota o campo da realidade relevante. Para além dela, há apenas inexistência, invisibilidade e ausência não dialética. 
Esta linha torna-se uma fronteira que foi erigida pelo escravismo, o patriarcalismo e o colonialismo europeu. Do outro lado deste marco divisor, como expressa Santos (2010), encontram-se diferentes grupos humanos, dentre eles os/as integrantes da população negra que torna a existência visível valorizada, a qual passa pela construção de um "pensamento crítico da modernidade que constitua uma resistência epistemológica à injustiça social e à justiça cognitiva" (MARTINS, 2019, p. 533). Essa construção passa por processo educativo que respeite a diversidade, que seja inclusiva e também libertadora, dentro da qual tenhamos a multiplicidade de ideias e pensamentos quanto à complexidade a qual se mostra presente quando os/as "componentes que constituem um todo (como o econômico, o político, o sociológico, o psicológico, o afetivo, o mitológico) são inseparáveis e existe um tecido interdependente, interativo e inter-retroativo entre as partes e o todo, o todo e as partes" (MORIN, 2003, p. 14), pois o educar apresenta uma "importância fundamental para mudanças estruturais. É o lugar estratégico para o desenvolvimento de mecanismos que permitam a ruptura com o passado e o presente opressores" (BOTELHO; MARQUES, 2015, p. 31).

$\mathrm{O}$ ato de incluir e de pensar campos e possibilidades discursivas, que estejam além do campo do natural, não tem sido um ato recorrente entre os/as profissionais que atuam no campo da Biologia. A saúde, por exemplo, um tema clássico nos manuais tanto do ensino Fundamental quanto do Médio, não traz qualquer tipo de articulação entre a incidência de doenças e grupos populacionais, permitindo passar ao largo das discussões as doenças prevalentes na população negra. O desejo de mudança e o de ir além de determinadas limitações fizeram com que a Biologia emergisse enquanto um corpo robusto dentro do campo acadêmico ao longo dos anos oitocentos e acreditamos que seja este desejo de inconformidade que necessita ser recuperado, ao longo do século XXI no sentido de que a Biologia contribua para uma educação decolonial e emancipadora.

Assim, com esse posicionamento, tanto científico quanto crítico, a Biologia se configura como uma área que pode e deve participar das 
discussões que visam enfrentar as desigualdades muitas vezes gestadas por meio do racismo, do preconceito e da discriminação racial, uma vez que se coloca ao lado dos seres vivos, das complexidades da vida. Para interligar esses dois campos, porquanto "há um deslocamento do saber fundado nas estruturas visíveis dos seres vivos, para o invisível, enunciado pelo conceito de organização interna" (PORTOCARRERO, 2009, p. 131-132). Pensada dessa forma, a Biologia não se encontra como um dado, uma informação pronta e acabada, mas como um processo, uma construção, também, no campo discursivo da Educação das Relações Raciais.

Sendo assim, o presente texto objetiva articular conhecimentos da Citologia à Educação das Relações Étnico-Raciais, buscando contribuir com a formação inicial na perspectiva emancipatória visando à formação inicial de licenciandos/as em Ciências Biológicas para o cumprimento da Lei no 10.639/2003, introduzindo-os/as no debate de uma educação decolonial. O presente manuscrito mostra-se dividido em três seções complementares. A primeira é o percurso metodológico no qual tem-se o período e o campo da pesquisa bem como o método utilizado para a obtenção dos resultados. Na segunda encontra-se o perfil dos/as estudantes bem como os temas e discussões da Biologia Celular que foram articulados à Lei no 10.639/2003, e finalizando a terceira seção, quando nas Considerações Finais são apresentadas as reflexões decorrentes dos resultados obtidos bem como indagações que poderão nortear novas produções textuais.

\section{PERCURSO METODOLÓGICO: coleta e sistematização dos dados}

Nos primeiros dias de aula dos semestres 2017-1, 2017-2, 2018-1 e 20182, aplicamos um questionário, contendo 34 questões objetivas e subjetivas, num total de 34, o qual foi elaborado para coletar informações de natureza sociocultural e de formação acadêmica dos grupos de discentes matriculados/as no Curso de Licenciatura em Ciências Biológicas da Universidade Federal da Paraíba (UFPB). Informações tais como cor, de acordo com as categorias do Instituto Brasileiro de Geografia e Estatística (IBGE), sexo, idade, religião, conhecimento da Lei no 10.639/2003, 
escolaridade do pai e da mãe, bem como alguns dos conceitos relativos ao componente curricular Biologia Celular foram coletados. O instrumento de pesquisa aplicado não permitia a identificação dos/as respondentes.

Antes de a digitação ser iniciada, numa planilha do Excel da Microsoft, os questionários eram sequencialmente numerados, sendo os dados filtrados por meio de ferramenta desse software (SILVA; SOARES; SILVA, 2015). Neste artigo, a numeração atribuída foi substituída por nomes de pessoas do Antigo Egito (Ta-Meri), território no qual habitavam povos de pele negra, segundo Diop (2010) kmt ou segundo Araújo (2015), os/as remetu kemi.

As experiências didáticas aqui descritas faziam parte do plano de trabalho do Projeto de Tutoria da UFPB, o qual objetiva diminuir a retenção no componente curricular Biologia Celular. No semestre 2017-1, aprovamos a proposta intitulada Ensino de Fisiologia Celular: o uso de metodologias criativas e motivacionais como instrumentos para a melhoria do processo de ensino/aprendizagem, a qual foi reapresentada e renovada nos períodos, 2017-2, 2018-1 e 2018-2. Assim garantia-se a presença de pelo menos dois bolsistas, do curso de Licenciatura em Ciências Biológicas, os/as quais participavam ativamente de todas as atividades. Ao longo das duas primeiras experiências de desenvolvimento do projeto, em 2017-2 e 2018-1, contamos também com a participação de dois estudantes do Programa de Pós-Graduação em Educação da UFPB (PPGE), que, junto a uma turma do diurno e outro/a do noturno, desenvolveram seus estágios de docência.

No decorrer das aulas teóricas expositivas dialogadas, diferentes assuntos relacionados à população negra foram inseridos e discutidos, concernentes aos temas do conteúdo programático, com o objetivo de articular o processo de ensino e aprendizagem de Biologia Celular com a Lei no 10.639/2003, bem como para exemplificar aos/às discentes como esta área, integrante do campo das Ciências Naturais, poderia ser discutida em sala de aula, de forma interseccional, com temática racial. Optamos por esta estratégia de ação, pois ela exige "a participação ativa dos estudantes, cujo conhecimento prévio deve ser considerado e pode ser tomado como ponto de partida. O professor leva os estudantes a 
questionarem, interpretarem e discutirem o objeto de estudo, a partir do conhecimento e do confronto com a realidade" (ANASTASIOU; ALVES, 2004, p. 79).

Ao longo dos encontros, dois por semana, com duração total de quatro horas semanais, os/as discentes eram estimulados/as a formarem equipes e a proporem temas que articulassem conteúdos da disciplina e que também estivessem relacionados à população negra, cujos resultados seriam apresentados, no formato de banner, em data previamente determinada. Cada grupo era orientado no levantamento bibliográfico, o que permitiria a escolha do tema de estudo a ser exposto no formato de painel.

Quanto às atividades didáticas, elas ocorriam nos primeiros seis meses do ano. A sessão de apresentação acontecia no dia 13 de maio, data da "Abolição da Escravidão" que foi ressignificada como o Dia Nacional de Denúncia da Discriminação Racial no Brasil. Quando as aulas transcorriam nos seis meses finais do ano, as exposições eram realizadas em novembro ${ }^{4}$ de forma a estimular os/as futuros/as docentes a atuarem, a partir de área profissional, nas atividades alusivas ao mês da Consciência Negra, uma vez que o artigo 79 B, da Lei no 10.639/2003, torna o dia 20 de novembro como "Dia Nacional da Consciência Negra5", data de celebração proposta, originalmente, pelo Movimento Negro Unificado (MNU) em 1978 (DOMINGUES, 2007). Tanto numa oportunidade quanto na outra havia todo um acompanhamento e orientação para que eles/as pudessem trabalhar de forma a levarem a Lei no 10.639/2003 para dentro de suas futuras salas de aula.

\section{PERFIL DOS/AS ESTUDANTES E A CONSTRUÇÃO DE UMA METODOLOGIA INOVADORA PARA O PROCESSO DE ENSINO/APRENDIZAGEM DE BIOLOGIA CELULAR}

\footnotetext{
${ }^{4}$ Este mês seria a culminância das ações didáticas.

5 Lei no 10.639/2003. Disponível em: <

http://www.planalto.gov.br/ccivil_03/leis/2003/L10.639.htm>. Acesso em 14 dez 2019.
} 
Ao longo dos quatro semestres, as discussões foram levadas a efeito com um total de 120 discentes, sendo $86(71,7 \%)$ e $34(28,3 \%)$ do diurno e do noturno, respectivamente. Havia uma presença feminina levemente mais elevada que a masculina, $66(55,0 \%)$ e $54(45,0 \%)$ respectivamente. O maior número de participantes do curso diurno pode ser explicado, pois 0 componente curricular Biologia Celular é ofertado duas vezes ao ano, enquanto para o noturno apenas uma. Quanto à cor das pessoas, tínhamos $58(48,3 \%)$ de pardas e $45(37,5 \%)$ brancas, tendo-se ainda que entre os/as respondentes 12 (10\%) autodeclararam-se como sendo pretas e $5(4,2 \%)$ como sendo amarelas. No tocante ao credo religioso, 11 foram as religiões informadas ${ }^{6}$, sendo que as duas mais numerosas foram a católica e a protestante com, respectivamente, 40 (33,3\%) e 10 (8,3\%).

Dados tais como idade, cor e religião não são frequentemente trabalhados no campo da Biologia, porém foram coletados e apresentados, pois diferentes variáveis contribuem para o entendimento da condição social da pessoa (DURANDl; SOUSA, 2002). Concordamos com Ciurana (2012,

p. 89) quanto à importância do reconhecimento das "cegueiras do conhecimento. Ver o papel dos mitos, das crenças, das religiões, os imprintings culturais", uma vez que a cor e a religião, por exemplo, dos/as discentes acompanham no interior da sala de aula. Esta presença entra em concordância com as Orientações e Ações para a Educação das Relações Étnico-Raciais (BRASIL, 2006), uma vez que o/a discente apresenta uma identidade singular que o/a insere em uma coletividade específica.

Mesmo nas aulas quando as plantas vinculadas a religiões de matrizes africanas, como o Candomblé, foram abordadas, nunca houve qualquer manifestação de constrangimento e/ou de racismo religioso por parte dos/as discentes. Acreditamos que um ponto importante que evitou problemas foi justamente a estreita e íntima articulação da temática ao programa da disciplina

\footnotetext{
${ }^{6}$ As demais religiões foram: ortodoxos 3 (2,5\%); espíritas, evangélicos/as e testemunhas de Jeová e mórmons tiveram 2 (1,7\%) cada; adventistas, wicca; cristãos reformados/as e outros credos foram 1 cada (0,8\%). As pessoas ateias e que não responderam 42 (35\%) e 13 (10,8\%), respectivamente.
} 
Biologia Celular, uma vez que houve um momento de "convívio e respeito entre as dimensões "científica" e "tradicional" (VERRANGIA, 2010, np).

Uma característica encontrada nas turmas foi que a maioria dos/as discentes $^{7}$, (100) 83,3\%, acreditava que os conteúdos da Biologia poderiam ser aplicados em sua vida diária. Essa opinião permitiu um maior interesse dos grupos pela proposta levada a efeito ao longo das aulas.

Esta experiência educativa, na qual 0 processo de ensino/aprendizagem é tratado de forma transversal com a Lei no 10.639/2003, surgiu de inquietações que se enraizaram em nossa mente, quando de participações na formação de professores/as, pois ao perguntar para eles/as como, a partir da Biologia, desenvolveriam atividades com o objetivo de obedecer a este marco legal, de forma recorrente, ano após ano, eles/as diziam que trabalhariam a temática do Candomblé, a da Escravidão assim como a do preconceito e da discriminação. Percebia, logo em seguida, que eles/as não estavam preparados/as para discutirem tais temas em sala de aula, pois nas respostas não havia propostas que articulassem os temas citados com a Biologia e para os diferentes temas, preconceito e discriminação eram sinônimos e, muitas vezes, por afirmarem a inexistência da "raça", o racismo não era sequer citado.

Essas discussões nos motivaram a levar o tema da Educação das Relações Étnico-Raciais para a sala de aula do Curso de Licenciatura em Ciências, UFPB, buscando, assim, repensar o currículo dos/as futuros/as professores/as de Biologia. Ao repetir a pergunta, obtinha as mesmas respostas como ocorreu ao longo das formações. Assim iniciamos um processo de reestruturação do conteúdo programático que seria discutido ao longo das aulas, pois em concordância com as Diretrizes Curriculares Nacionais para a Educação das Relações Étnico-Raciais e para o Ensino de História e Cultura Afro-Brasileira e Africana (BRASIL, 2004, p. 15), os estabelecimentos escolares e "seus professores não podem improvisar. É imperioso que se desconstruam as mentalidades racista e discriminadora de

$716(13,3 \%)$ afirmaram que não e $4(3,3 \%)$ não responderam a esta pergunta. 
forma a se superar o paradigma do Eurocentrismo que traz em seu âmago uma prática da universalidade (ARAÚJO; MAESO, 2016), reestruturando relações étnico-raciais e sociais, desalienando processos pedagógicos". Neste sentido, é estratégico desenvolver um olhar diferenciado e inclusivo proposto nas Orientações e Ações para a Educação das Relações ÉtnicoRaciais (BRASIL, 2006), as quais sugerem temas que podem ser desenvolvidos pela Biologia, dentre eles a Saúde da População Negra. Levamos ainda em consideração as palavras de Coelho (2018), pois deve e pode ser ponderada, também, a parcela de responsabilidade dos cursos de licenciatura na implantação desta legislação.

$\mathrm{Na}$ aula introdutória, apresentamos, a cada semestre, a Lei no 10.639/2003 bem como o Parecer ${ }^{8}$ emitido pela Professora Doutora Petronilha Beatriz Gonçalves e Silva, conselheira do Conselho Nacional de Educação, o qual, dentre outros temas, ressalta "as contribuições do Egito para a ciência e filosofia ocidentais". Pontos da Resolução 01/20049 eram citados para justificar a inserção dos temas ligados à população negra ao longo das aulas, pois as Instituições de

Ensino Superior incluirão nos conteúdos de disciplinas e atividades curriculares dos cursos que ministram a Educação das Relações Étnico-Raciais, bem como o tratamento de questões e temáticas que dizem respeito aos afrodescendentes, nos termos explicitados no Parecer CNE/CP 3/2004.

No âmbito local, citávamos a regulamentação da Lei no 10.639/2003, na cidade de João Pessoa, ocorrida em 2006, a qual, de acordo com as Diretrizes para implementação, amplia a aplicação deste marco legal para todas as áreas de conhecimento havendo ainda a obrigatoriedade da discussão do tema pelo menos uma vez a cada bimestre (ROCHA; SILVA, 2013). Trazíamos ainda a resolução 016/2015 do Conselho Superior de Pesquisa Ensino e Extensão da UFPB, que, no artigo 26, regulamenta a presença do componente curricular Educação para as Relações Étnico-

\footnotetext{
8 Parecer 003/2004. Disponível em:

<http://portal.mec.gov.br/dmdocuments/cnecp_003.pdf>. Acesso em 14 dez 2019.

9 Resolução CNE No 1, de 17 de junho de 2004.

Disponível em: < http://portal.mec.gov.br/cne/arquivos/pdf/res012004.pdf >. Acesso em 14 dez 2019.
} 
Raciais para todos os cursos de graduação da UFPB. Ao trazer a Lei no 10.639/2003 e alguns dos desdobramentos, aqui citados, tínhamos sustentação da legislação em vigor para nossa estratégia de articulação da Biologia.

A cada semestre do desenvolvimento das experiências didáticas, buscamos captar, nos diferentes grupos de discentes, a estrutura a partir da qual as diferentes doenças se desenvolviam. As respostas eram um órgão, um tecido, e na ausência da resposta mais adequada, trazia então um conceito de célula, no qual ela é apresentada como sendo "uma entidade estrutural e funcional fundamental dos seres vivos" (DE ROBERTIS; HIB, PONZIO, 2003, p. 1). A partir da célula, instalam-se as mais diferentes doenças, sendo que esses são assuntos abordados nos Ensinos Fundamental e Médio. Assim, com este discurso, conseguia conectar os conteúdos da disciplina Citologia com uma ação educativa voltada para a Educação das Relações-Raciais, tendo como foco a Lei no 10.639/2003 e direcionando as discussões para as doenças prevalentes na população negra.

Com esta prática didática transversal, trabalhamos com o pensamento de Paulo Freire (2000, p. 40), para quem a educação pode ser considerada que: "é sempre uma certa teoria do conhecimento posta em prática", não importando se é um "conhecimento já existente ou se achamos na busca da produção do conhecimento não existente ainda" (2000, p. 63), pois através de uma consciência crítica, descobrimos que sabemos pouco e, a partir de nosso lugar no cosmos, inquietamos por saber mais (FREIRE, 2005). O fato de este movimento de inquietude ser realmente crítico, emancipatório e decolonial, ele deve nos levar a colocar em prática o giro epistêmico ao longo do qual se aprende, se desaprende, e volta-se a aprender novamente (MIGNOLO, 2008). Sem que ele seja dado, estaremos repetindo praticamente uma forma de "compra" e "venda", na qual a escola se transforma em um mercado transformando "o professor num especialista, que vende e distribui um "conhecimento empacotado"; o aluno, no cliente que compra e "come" este conhecimento" (FREIRE, 1978, p. 14). 
Com o transcorrer das aulas, a estratégia da exposição dialogada mostrou-se de profunda importância, pois permitiu um amplo canal de troca de comunicação. Para os mais diferentes conteúdos, havia um questionamento para os/as discentes: como aquele ponto se articularia com a Lei no 10.639/2003? A partir de um determinado momento, em cada um dos semestres, esta pergunta passou a ser feita pelos/as discentes e ouvi-la foi um momento muito rico, o qual nos deu uma certeza de que havia estudantes sensibilizados/as pela proposta didática.

No quadro 1, apresentamos a relação de temas levados para as aulas e os assuntos referentes à Lei no 10.639/2003 que foram discutidos, ao longo das aulas, com os/as discentes.

\begin{tabular}{|c|c|c|}
\hline \multicolumn{3}{|c|}{$\begin{array}{l}\text { Quadro 1. Temas das aulas da disciplina Biologia Celular articulados à Lei no 10.639/2003 } \\
\text { desenvolvidos ao longo dos semestres } 2017-1,2017-2,2018-1 \text { e } 2018-2\end{array}$} \\
\hline $\begin{array}{l}\text { Conteúdos } \\
\text { programáticos }\end{array}$ & Temas das aulas & Assuntos articulados \\
\hline \multirow{3}{*}{$\begin{array}{l}\text { Técnicas de } \\
\text { preparação } \\
\text { tecidual }\end{array}$} & Microscopia & $\begin{array}{l}\text { Cientistas negros: Tito Livio de Castro e George } \\
\text { Washington Carver. Personalidades negras }\end{array}$ \\
\hline & Fixação tecidual & Mumificação no Egito Antigo (Ta-Meri) \\
\hline & Coloração & $\begin{array}{l}\text { Uso do Aloe vera (Babosa) no Antigo Egito e } \\
\text { do Dioscorea trifida (Inhame). }\end{array}$ \\
\hline Membrana & Permeabilidade celular & Hipertensão arterial e AIDS. \\
\hline Citoesqueleto & Formato celular & $\begin{array}{l}\text { Anemia/doença falciforme e fragmentos de } \\
\text { epiderme das Tradescantia spathacea } \\
\text { (espada de lansã ou abacaxi-roxo) e de } \\
\text { Kalanchoe pinnata (folha-da-costa). }\end{array}$ \\
\hline $\begin{array}{l}\text { Núcleo e } \\
\text { cromatina }\end{array}$ & $\begin{array}{l}\text { Núcleo, cromatina, } \\
\text { hereditariedade, controle } \\
\text { bioquímico do ciclo celular }\end{array}$ & $\begin{array}{l}\text { Câncer de próstata, miomas uterinos, } \\
\text { Anemia/doença falciforme. Saúde da } \\
\text { População Negra. História de vida de } \\
\text { Henrietta Lacks. }\end{array}$ \\
\hline \multirow{3}{*}{$\begin{array}{l}\text { Organelas } \\
\text { citoplasmáticas }\end{array}$} & $\begin{array}{l}\text { Mitocôndrias, DNA mitocondrial } \\
\text { e origens da humanidade }\end{array}$ & Origem da humanidade em África. \\
\hline & Complexo Golgiense & Cientistas negros: Ernest Everett Just. \\
\hline & Lisossomos & $\begin{array}{l}\text { Apoptose, Diabetes tipo 2, glaucoma, Saúde } \\
\text { da População Negra. }\end{array}$ \\
\hline
\end{tabular}

Fonte: Programa da disciplina Biologia Celular.

As discussões realizadas nos encontros dialógicos eram aprofundadas nos momentos de orientação com os/as tutores/as ou com os/as estudantes de Pós-Graduação em Educação que desenvolviam seu estágio de docência na disciplina. Dessa interação, novas proposições surgiam, algumas vindas a partir de discussões ocorridas em sala de aula. Assim, 
emergiram os temas que foram apresentados pelos discentes e que são detalhados no quadro 2. Ao longo dos semestres 2017-1, 2017-2, 2018-1 e 2018-2, foram apresentados 34 banners, os quais permitiram que a Biologia Celular pudesse ser vista como uma área do conhecimento apta a participar da construção de um currículo emancipador e decolonial.

Como pode ser visto no quadro 2, não há uma rigidez quanto à conexão dos temas ligados à Lei no 10.639/2003, pois um determinado assunto pode ser apresentado em mais de um tema da Citologia. Isto gera uma flexibilidade que permite que o conteúdo venha a ser discutido em sala de aula em diferentes momentos do semestre, contribuindo assim para a aprendizagem.

\begin{tabular}{|c|c|l|c|}
\hline \multicolumn{3}{|c|}{ Quadro 2. Relação de trabalhos apresentados pelos/as discentes e as propostas de } \\
articulação com o Ensino do Citologia com a Lei no 10.639/2003
\end{tabular}




\begin{tabular}{|c|c|c|c|}
\hline & & 10.639/2003". & \\
\hline & 10 & $\begin{array}{l}\text { "Anemia hemolítica e a Lei no } \\
\text { 10.639/2003: uma proposta } \\
\text { interdisciplinar". }\end{array}$ & $\begin{array}{c}\text { Núcleo, cromatina, hereditariedade, } \\
\text { controle bioquímico do ciclo celular. } \\
\text { Microscopia/Saúde da População } \\
\text { Negra. }\end{array}$ \\
\hline & 11 & $\begin{array}{l}\text { "Técnica para identificação de } \\
\text { portadores de anemia falciforme: } \\
\text { interfaces entre o ensino de Biologia } \\
\text { e a Lei no } 10.639 / 2003 \text { ". }\end{array}$ & $\begin{array}{c}\text { Núcleo, cromatina, hereditariedade, } \\
\text { controle bioquímico do ciclo celular. } \\
\text { Microscopia/Saúde da População } \\
\text { Negra. }\end{array}$ \\
\hline & 12 & $\begin{array}{l}\text { "A Lei no } 10.639 / 2003 \text { e suas } \\
\text { implicações no ensino de biologia e } \\
\text { fisiologia celular". }\end{array}$ & $\begin{array}{l}\text { Técnicas de fixação e preparação } \\
\text { tecidual/permeabilidade celular. }\end{array}$ \\
\hline \multirow{6}{*}{2017.2} & 13 & $\begin{array}{l}\text { "Filhos da África: descendência por } \\
\text { linhagens de mitocôndrias". }\end{array}$ & $\begin{array}{l}\text { Mitocôndrias, DNA mitocondrial e } \\
\text { origens da humanidade. }\end{array}$ \\
\hline & 14 & $\begin{array}{l}\text { "À luz da Lei no 10.639/2003, } \\
\text { Antonieta de Barros: correntes que } \\
\text { foram quebradas". }\end{array}$ & Personalidades negras/educação. \\
\hline & 15 & $\begin{array}{l}\text { "Professora Lúcia de Fátima Julio: } \\
\text { importância da discussão da } \\
\text { implementação da Lei no } \\
\text { 10.639/2003 no ambiente escolar e } \\
\text { acadêmico". }\end{array}$ & Personalidades negras/educação. \\
\hline & 16 & $\begin{array}{l}\text { "Merit Ptah: uma análise da mulher } \\
\text { negra no contexto histórico da } \\
\text { ciência". }\end{array}$ & Personalidades negras/educação. \\
\hline & 17 & $\begin{array}{l}\text { "Juliano Moreira: análise de sua } \\
\text { contribuição social e científica". }\end{array}$ & Personalidades negras/educação. \\
\hline & 18 & "Henrietta Lacks". & $\begin{array}{c}\text { Núcleo, cromatina, hereditariedade, } \\
\text { controle bioquímico do ciclo celular. } \\
\text { Microscopia/Saúde da População } \\
\text { Negra. }\end{array}$ \\
\hline \multirow{6}{*}{2018.1} & 19 & $\begin{array}{l}\text { "A mumificação e a aplicação da } \\
\text { Lei no } 10.639 / 2003 \text { no processo de } \\
\text { ensino/aprendizagem de citologia". }\end{array}$ & $\begin{array}{l}\text { Técnicas de fixação e preparação } \\
\text { tecidual/permeabilidade celular. }\end{array}$ \\
\hline & 20 & $\begin{array}{l}\text { "Anemia falciforme e a população } \\
\text { negra". }\end{array}$ & $\begin{array}{c}\text { Núcleo, cromatina, hereditariedade, } \\
\text { controle bioquímico do ciclo celular. } \\
\text { Microscopia/Saúde da População } \\
\text { Negra. }\end{array}$ \\
\hline & 21 & $\begin{array}{l}\text { "A relação da fermentação natural } \\
\text { com o ensino da cultura negra pela } \\
\text { Lei no } 10.639 / 2003 \text { e o ensino da } \\
\text { biologia". }\end{array}$ & $\begin{array}{l}\text { Mitocôndrias, DNA mitocondrial e } \\
\text { origens da humanidade. }\end{array}$ \\
\hline & 22 & $\begin{array}{l}\text { "O uso da babosa na aplicação da } \\
\text { Lei no } 10.639 / 2003 \text { melhorando o } \\
\text { ensino e aprendizagem". }\end{array}$ & $\begin{array}{c}\text { Técnicas de fixação e preparação } \\
\text { tecidual/coloração. }\end{array}$ \\
\hline & 23 & $\begin{array}{l}\text { "Aquaporinas e a pele negra no } \\
\text { ensino de biologia celular: atuação } \\
\text { dos hidratantes na pele da } \\
\text { população negra, à luz da Lei no } \\
\text { 10.639/2003". }\end{array}$ & $\begin{array}{c}\text { Proteínas da superfície celular/Saúde } \\
\text { da População Negra. }\end{array}$ \\
\hline & 24 & $\begin{array}{l}\text { "O milagre da evolução: deficiência } \\
\text { da g6pd confere aos negros e seus } \\
\text { descendentes resistência contra } \\
\text { parasitas maláricos". }\end{array}$ & $\begin{array}{c}\text { Núcleo, cromatina, hereditariedade, } \\
\text { controle bioquímico do ciclo celular. } \\
\text { Microscopia/Saúde da População } \\
\text { Negra. }\end{array}$ \\
\hline
\end{tabular}




\begin{tabular}{|c|c|c|c|}
\hline & 25 & $\begin{array}{l}\text { "Prevalência da hepatite B na } \\
\text { população negra: possibilidades de } \\
\text { discussão da Lei no 10.639/2003". }\end{array}$ & Apoptose/Saúde da População Negra \\
\hline & 26 & $\begin{array}{l}\text { "Ernest Everet Just: análise da } \\
\text { contribuição de um cientista negro". }\end{array}$ & $\begin{array}{l}\text { Personalidades negras/educação/ } \\
\text { microscopia. }\end{array}$ \\
\hline & 27 & $\begin{array}{l}\text { "AIDS correlacionada à Lei no } \\
\text { 10.639/2003". }\end{array}$ & $\begin{array}{c}\text { Proteínas da superfície celular/Saúde } \\
\text { da População Negra. }\end{array}$ \\
\hline & 28 & $\begin{array}{l}\text { "Hipertensão arterial: relacionada } \\
\text { com a Lei } 10.639 / 03 " .\end{array}$ & $\begin{array}{c}\text { Proteínas da superfície celular/Saúde } \\
\text { da População Negra. }\end{array}$ \\
\hline & 29 & $\begin{array}{l}\text { "Anemia falciforme e a população } \\
\text { negra no ensino de Biologia Celular } \\
\text { abordando a Lei no 10.639/2003". }\end{array}$ & $\begin{array}{c}\text { Núcleo, cromatina, hereditariedade, } \\
\text { controle bioquímico do ciclo celular. } \\
\text { Microscopia/Saúde da População } \\
\text { Negra. }\end{array}$ \\
\hline \multirow{5}{*}{2018.2} & 30 & $\begin{array}{l}\text { "O estudo de citologia associado } \\
\text { com a mumificação e a Lei no } \\
\text { 10.639/2003". }\end{array}$ & $\begin{array}{l}\text { Técnicas de fixação e preparação } \\
\text { tecidual/permeabilidade celular. }\end{array}$ \\
\hline & 31 & $\begin{array}{l}\text { "Eva Mitocondrial: a origem africana } \\
\text { do homem moderno (Lei no } \\
\text { 10.639/2003". }\end{array}$ & $\begin{array}{l}\text { Mitocôndrias, DNA mitocondrial e } \\
\text { origens da humanidade. }\end{array}$ \\
\hline & 32 & $\begin{array}{l}\text { "Os avanços do cientista George } \\
\text { Washington Carver e sua relação } \\
\text { com a Lei no 10.639/2003." }\end{array}$ & $\begin{array}{l}\text { Personalidades negras/educação/ } \\
\text { microscopia. }\end{array}$ \\
\hline & 33 & $\begin{array}{l}\text { "O uso da Aloe vera no Egito Antigo } \\
\text { associado com a Lei no 10.639/2003, } \\
\text { analisando as propriedades } \\
\text { moleculares, farmacológicas e } \\
\text { medicinais da planta". }\end{array}$ & $\begin{array}{c}\text { Técnicas de fixação e preparação } \\
\text { tecidual/coloração. }\end{array}$ \\
\hline & 34 & $\begin{array}{l}\text { "Anemia falciforme e a população } \\
\text { negra no ensino de biologia celular } \\
\text { abordando a Lei no 10.639/2003". }\end{array}$ & $\begin{array}{c}\text { Núcleo, cromatina, hereditariedade, } \\
\text { controle bioquímico do ciclo celular. } \\
\text { Microscopia/Saúde da População } \\
\text { Negra. }\end{array}$ \\
\hline
\end{tabular}

Fonte: Projeto de tutoria. Ensino de Fisiologia Celular: o uso de metodologias criativas e motivacionais como instrumentos para a melhoria do processo de ensino/aprendizagem. Semestres 2017-1, 2017-2, 2018-1 e 2018-2.

\section{APOPTOSE, SAÚDE DA POPULAÇÃO NEGRA}

Como pode ser observado no quadro 2, tivemos 34 apresentações ao longo dos 4 semestres, sendo que 3 (8,8\%), os experimentos de número 4, 5 e 25, foram classificados na temática: Apoptose (Morte celular programada) e Saúde da População Negra. A primeira é "um processo fisiológico essencial para a eliminação de células em excesso ou que não são mais necessárias ao organismo, atuando na homeostase dos tecidos; entretanto, esse fenômeno também está envolvido em condições patológicas" (LUCHS; PANTALEÃO, 2010, p. 495). A segunda ${ }^{10}$, por sua vez, é entendida como um conjunto de estudos, pesquisas e propostas voltadas para a atenção à

10 Política Nacional de Saúde Integral da População Negra. Disponível em: <http://bvsms.saude.gov.br/bvs/publicacoes/saudepopnegra.pdf>. Acesso em 1 jan 2020. 
saúde, que emergem a partir de ações do Movimento Social Negro, tendo por base conhecimentos de ordem inter e transdisciplinar oriundos das Ciências Médicas e Humanas por meio da constatação de que o racismo a que estão expostos, homens e mulheres negros/as, gera condições perversas e adversas as quais somente poderão ser dirimidas com implementação de políticas públicas capazes de reconhecer e dirimir estas condições ${ }^{11}$, pois, em concordância com Lopes (2005, p. 18), "Indígenas, negros e brancos ocupam lugares desiguais nas redes sociais e trazem consigo experiências também desiguais ao nascer, viver, adoecer e morrer".

A apoptose mostra-se relacionada ao desenvolvimento do glaucoma (MARIGO; CRONEMBERGER; CALIXTO, 2001) bem como do Diabetes tipo 2 (LEAL; VOLTARELLI, 2010): duas doenças prevalentes na população negra (GREENIDGE; DWECK, 1988, BRASIL, 2001 a. MARSHALL JR, 2005).

Em relação a estes temas, foi inovador articular a ocorrência da apoptose com a Saúde da População Negra, bem como apresentar para os diferentes grupos de discentes estas duas morbidades, glaucoma e diabetes tipo 2, como sendo prevalentes entre negros/as. Para todos os grupos com os quais trabalhamos, foi também uma grande novidade a informação de que existem doenças prevalentes em determinados grupos humanos, tais como negros e judeus. No Brasil, pelo menos dois textos do Ministério da Saúde, ambos do ano de 2001, o Manual de doenças mais importantes, por razões étnicas, na população brasileira afro-descendente e o Manual de diagnóstico e tratamento de doença falciforme alertam para doenças prevalentes na população negra, porém estes conhecimentos terminam por não fazer parte dos manuais escolares, o que nos coloca diante de inexistências (SANTOS, 2002) e invisibilidades (ARAÚJO; MAESO, 2013) que poderão ser epistemologicamente superadas por meio de uma pedagogia emancipatória e decolonial.

1 Subsídios para o debate. Disponível em:

http://bvsms.saude.gov.br/bvs/publicacoes/saudepopnegra.pdf. Acesso em 14 dez 2019.

Revista Exitus, Santarém/PA, Vol. 10, p. 01-32, e0201 10, 2020. 


\section{MITOCÔNDRIAS, DNA MITOCONDRIAL E ORIGENS DA HUMANIDADE}

Ao longo de todo o período estudado, 3 (8,8\%) apresentações, correspondentes aos banners 13,21 e 31, relacionaram-se à mitocôndria, uma organela citoplasmática presente em todas as células com exceção das hemácias de mamíferos e as bactérias, cuja principal função biológica divulgada é a produção de energia metabólica sob a forma de adenosina trifosfato (ATP), sendo conhecida como as usinas energéticas da célula (DE ROBERTIS; HIB, PONZIO, 2003). As mitocôndrias são transmitidas, de uma geração imediatamente anterior para a próxima, por meio de herança materna (NASSEH, 2001) e como seu material hereditário, de formato circular, não se hibridiza com o paterno, torna-se uma ferramenta molecular ímpar para traçarmos nossa ancestralidade por meio da linha matrilinear. O DNA mitocondrial foi objeto dos trabalhos 13 e 31.

O banner 21 explorou a capacidade do citoplasma na produção de um metabólito. O produto final da via glicolítica (fermentação), que impulsiona a produção de energia pela organela, o piruvato, pode ser utilizado para produção de álcool (DE ROBERTIS; HIB, PONZIO, 2003). Esta prática abordou a utilização do piruvato na produção de uma cerveja grossa, encorpada e energética, muito semelhante à chamada de henket, uma bebida produzida e apreciada pelos/as remetu kemi, os/as moradores/as do Ta-Meri (CANHÃO, 2015).

Neste grupo, encontramos discentes que desconheciam que o DNA mitocondrial poderia ser utilizado para a pesquisa de nossa ancestralidade, porém a novidade foi a produção da cerveja no Ta-Meri, já por volta de 3500 anos antes de Cristo (OLIVER, 2012).

\section{NÚCLEO, CROMATINA, HEREDITARIEDADE, CONTROLE BIOQUÍMICO DO CICLO CELULAR MICROSCOPIA/SAÚDE DA POPULAÇÃO NEGRA}

O núcleo celular é uma organela típica dos seres eucarióticos sendo que o seu material hereditário é proveniente $50 \%$ da mãe e $50 \%$ do pai. É o núcleo que, ao se dividir, gera novas células levando tanto ao crescimento normal do organismo quanto à produção de células anormais, devido à 
presença de mutações, as quais levam, por exemplo, ao desenvolvimento dos miomas uterinos, do câncer de próstata, da anemia falciforme (AF) e da doença falciforme (DF), morbidades prevalentes na população negra (BRASIL, 2001a) que se originam a partir de mutações que ocorrem em genes localizados, respectivamente, no cromossomo sexual X (FARIA; GODINHO; RODRIGUES, 2008), 17 (AMENDOLA; VIEIRA, 2005) e 11 (SONATI; COSTA, 2008).

Nestas temáticas, contabilizamos o maior número de apresentações $10(29,4 \%)$ referentes aos banners $3,6,7,10,11,18,20,24,29$ e 34. Neste grupo, encontramos atividades didáticas ligadas à $D F$ bem como à $A F$, que totalizaram $7(20,6 \%)$. Os experimentos $6,7,10,11,20,29$ e 34 estiveram voltados para essas duas doenças prevalentes na população negra. Buscamos impedir que os/as discentes entendessem as duas morbidades citadas como sendo sinônimas. Apresentávamos para eles/as pontos que permitissem a diferenciação entre ambas, pois a

\begin{abstract}
Doença Falciforme é um termo genérico usado para determinar um grupo de alterações genéticas caracterizadas pelo predomínio da hemoglobina (HbS). Essas alterações incluem a anemia falciforme (Hb SS), e as duplas heterozigoses, ou seja, as associações com d Hb $\mathrm{S}$ com outras variantes de hemoglobinas, tais como $\mathrm{Hb} \mathrm{D}, \mathrm{Hb} \mathrm{C}$, e as alterações com talassemias ( $\mathrm{Hb} S / \beta^{\circ}$ talassemia, $\mathrm{Hb} S / \beta^{+}$talassemia, $\mathrm{Hb} S / \alpha$ talassemia) (BRASIL, 2001, p. 22b).
\end{abstract}

Decidimos ainda por discutir com os/as discentes, das diferentes turmas, o manual do professor ${ }^{12}$ e o do paciente ${ }^{13}$, os quais apresentam grande importância, uma vez que vão além de descreverem as hemácias em forma de foice, uma morfologia que identifica a doença. Apresentávamos também algumas características fenotípicas/fisiológicas das pessoas falcêmicas, tais como: o priapismo, a menarca tardia, a dificuldade da cicatrização de ferimentos, a contraindicação à natação, a necessidade de urinar com mais frequência, crise de dor, icterícia (cor amarela nos olhos), síndrome mão-pé, "a inflamação aguda dos tecidos que

\footnotetext{
12 Manual do professor. Disponível em: < http://bvsms.saude.gov.br/bvs/publicacoes/anvisa/professor.pdf>. Acesso em 14 jan 2020. 13 Manual do paciente. Disponível em: <http://bvsms.saude.gov.br/bvs/publicacoes/anvisa/paciente.pdf>. Acesso em 14 dez 2019.
} 
revertem os ossos dos tornozelos, punhos, mãos e pés12", infecções, úlcera de perna.

Neste grupo temático, também foram inclusas as atividades didáticas, 3 e 18, relativas à vida da mulher negra estadudinense Henrietta Lacks (19201951). Foram retiradas de seu corpo, sem sua permissão, em 1951, células que foram imortalizadas em laboratório; as primeiras de nossa espécie com as quais se obteve sucesso de crescimento in vitro. Livros e artigos científicos, muitas vezes, trazem a sigla HeLa, oriunda das letras iniciais do seu nome, mas, em geral, não explicam a origem. A história de vida da senhora Lacks foi inicialmente divulgada por meio do livro escrito por Rebecca Skloot: "A vida imortal de Henrietta Lacks' $14 "$, sendo que algumas páginas da obra eram divulgadas para os discentes ${ }^{15}$. Ela havia sido acometida por um tipo de câncer uterino, uma doença que altera a forma como as células normalmente se dividem, a mitose. As células oriundas da senhora Lacks são usadas nas mais variadas pesquisas que vão, por exemplo, do teste de cosméticos ao estudo da infecção pelo HIV (ALVES, 2014).

A inovação deu-se no sentido de demonstrar que estas morbidades podem interferir profundamente na vida social e escolar do/a portador/a, indo além da mera demonstração à morfologia da hemácia em forma de foice. No caso da Sra. Lacks, advertimos para a falta de ética de como foi tratada, pois a retirada e o uso de suas células foram feitos sem o seu consentimento. Sua família somente tomou conhecimento da retirada e do uso em 1973, ficando totalmente à margem dos valores financeiros que as células de Henrietta estavam gerando (GARGANTILHA, 2019).

\section{PERMEABILIDADE CELULAR/SAÚDE DA POPULAÇÃO NEGRA}

Acerca destas temáticas, foram $3(8,8 \%)$ atividades didáticas: as de número 23, 27 e 28. A de número 23, relacionada à permeabilidade celular, versou sobre as aquaporinas proteínas integrais da membrana plasmática

\footnotetext{
14 Em 2017, chegou ao mercado cinematográfico o filme com o mesmo título do livro, uma película dirigida por Georg C. Wolfe e recomendamos que os/as discentes assistissem ao filme.

${ }^{15}$ As páginas do livro estão disponível em:

<https://www.companhiadasletras.com.br/trechos/12974.pdf>. Acesso em 14 dez 2019.
}

Revista Exitus, Santarém/PA, Vol. 10, p. 01-32, e0201 10, 2020. 
(membrana celular), uma "película protetora" que envolve as nossas células, e que contribuem para a formação de um meio propício para as reações bioquímicas. É por meio das aquaporinas, que água e pequenos solutos neutros, como glicerol, ureia e silício (GASPAR, 2011), são transportados para o interior da célula, sendo por meio delas que os cremes hidratantes agem sobre a nossa pele. É, pois, por intermédio das aquaporinas que os hidratantes produzidos para as pessoas negras hidratam a pele.

A epidemia de aids, apresentada sob um recorte racial tendo por base dados disponibilizados no Boletim Epidemiológico do Ministério da Saúde, foi discutida no banner 27. A interação do HIV com receptores protéicos, da família CD-4 presentes na membrana plasmática de linfócitos e de macrófagos, duas células de sistema imunológico, ocorre por meio de uma proteína viral com receptores da membrana celular (GUPTA, 2012). Já a hipertensão arterial mostra-se relacionada a proteínas de transporte cátions presentes na membrana celular havendo a sugestão da inibição da bomba de sódio-potássio nas membranas plasmáticas musculares e vasos sanguíneos (AMODEO; HEIMANN, 1998). Ambas as doenças não dependem apenas de fatores biológicos, pois elas se mostram influenciadas pelo meio ambiente social, tais como: o racismo, a discriminação, o status socioeconômico e a vulnerabilidade social'16 (HENRY, 1988). A hipertensão também poderia ser discutida como um tema ligado ao núcleo celular e à hereditariedade, pois o controle da pressão sistólica seria influenciado por 15 poligenes ${ }^{17}$ (HARRAP, 2003).

Houve inovação ao apresentarmos as bases celulares dessas duas morbidades, bem como demonstrar para os/as discentes a prevalência de ambas na população negra.

\footnotetext{
16 Quando o assunto foi citado na aula, um discente achava que era racismo contra as pessoas negras. Foi uma das oportunidades que tive para conceituar e diferenciar o racismo do preconceito e da discriminação.

17 Gene que, individualmente, desenvolve ligeiro efeito sofre um fenótipo, mas em conjugação com alguns ou muitos outros genes, controla um traço quantitativo, tal como o peso corporal, cor dos olhos, cor da pele, altura.
} 


\section{PERSONALIDADES NEGRAS}

Neste grupo, tivemos 7 atividades didáticas $(20,6 \%)$, as de número 8 , $14,15,16,17,26$ e 32, que foram relacionados a cientistas/personalidades negras.

Um dos nomes trazidos foi o do psiquiatra baiano, Juliano Moreira (1873-1933), um dos fundadores do primeiro periódico brasileiro inteiramente voltado para a saúde mental, os Arquivos Brasileiros de Psiquiatria (1905), Neurologia e Ciências Afins. Esta presença causou grande surpresa, pois, para eles/as, o nome remetia, imediatamente, ao estabelecimento de saúde mental. Moreira foi um forte crítico à ideia da imagem negativa de que negros/as contribuíam, devido à mestiçagem, para a degeneração do povo brasileiro.

Nas aulas de microscopia, apresentamos para os/as discentes o brasileiro Tito Livio de Castro (1864-1890) bem como o estadunidense George Washington Carver (1864-1943) psiquiatra e botânico/agrônomo, respectivamente, os quais se utilizavam de microscópios. Ambos nasceram 24 anos e um ano, respectivamente, após o final da escravização em seus países, a saber, 1888 e 1865, e neste período histórico, para os/as estudantes, era inimaginável uma pessoa negra estar em atividade intelectualizada. Essa era uma visão preconceituosa, colonizada e também incentivada pelos manuais didáticos, nos quais, muitas vezes, negros/as são "apresentados nos livros de Física e de Ciências como atletas ou em funções de trabalhadores braçais" (MORAIS; SANTOS, 2019, p. 78).

Tito Livio de Castro (1893), em pleno período dos anos oitocentos, mostrava um pensamento arrojado ao defender a educação para as mulheres. Para ele, não havia argumentação científica que explicasse a inferioridade da mulher frente ao homem. Carver revolucionou a agricultura de seu tempo ao descobrir que o amendoim, soja e batata-doce cresciam em solos que haviam se exaurido devido ao excesso de uso por plantações de algodão. Então propôs a rotatividade, salvou a economia local e agregou valor econômico a essas culturas ao desenvolver um grande número de produtos (SILVA; PINHEIRO, 2019). 
O biólogo Ernest Everett Just (1883-1941), pioneiro nos estudos da Biologia do Desenvolvimento Ecológico (Eco-Devo), linha de trabalhos realizados no contexto natural, desenvolveu pesquisas nas quais descobriu o papel da membrana celular na interação entre o óvulo e o espermatozóide (BYRNES; ECKBERG, 2006). Com base no conhecimento atual, sabemos que os componentes químicos das membranas que permitem esta interação são os carboidratos, os quais são inseridos numa estrutura intracelular denominada de Complexo Golgiense e, por este motivo, na aula referente a esta estrutura, o nome do biólogo estadunidense era citado.

Os nomes das professoras Antonieta de Barros (1901-1952) e Lucia de Fátima Julio foram trazidos pelos/as estudantes ao longo das pesquisas que eram incentivados/as a desenvolverem. A primeira, natural de Florianópolis, era preocupada com a educação bem como com a emancipação da mulher e a segunda, paraibana, residente na cidade de Alagoa Grande, é uma defensora da melhoria das condições de Educação, em especial para a população quilombola, sendo também um importante papel na implementação da Lei no 10.639/2003 em sev estado.

Apresentar estes cientistas negros bem como as duas educadoras foi inovador e relevante, pois, nas aulas, buscamos a desmistificação de um ideário eurocentrista (ARAÚJO; MAESO, 2016). A perspectiva abordada buscou apresentar as produções científicas desenvolvidas por pesquisadores/as africanos/as e afrodescendentes (SILVA; PINHEIRO, 2019), contribuindo assim para a desconstrução de uma ciência aparentemente realizada por cientistas brancos/as, pois, em concordância com Benite; Silva; Alvino (2016), acreditamos que a democratização na educação passa pela inserção de sujeitos desconsiderados como sujeitos do conhecimento.

\section{TÉCNICAS DE FIXAÇÃO E PREPARAÇÃO TECIDUAL/PERMEABILIDADE CELULAR}

Nesta temática, foram apresentados os experimentos 1, 2, 9, 12, 19, 22 , 30 e 33 que representaram um total de $8(23,5 \%)$, destes um subtotal de 5 $(11,8 \%)$, os de número $1,2,12,19$ e 30, versaram sobre a mumificação química, um processo artificial de preservação de corpos inaugurados 
pelos/as remetu kemi que, originalmente, dissecavam os corpos usando um sal complexo chamado de natrão. Nas aulas práticas, este era substituído, com sucesso, por uma mistura de sal de cozinha com bicarbonato de sódio. Uma das ações destes agentes químicos é possibilitar a saída de água dos tecidos, devido à permeabilidade da membrana celular e ao fazer isto promovem a fixação tecidual.

Mumificar exigia conhecimentos tanto técnicos quanto religiosos, sendo um procedimento realizado em 14 etapas, de acordo com informações compiladas dos papiros de Boulaq, do Louvre 5158 e o de Harawa. A técnica, que durava em torno de 70 dias, tinha início com a lavagem do corpo da pessoa morta em locais próprios 18 , o envio do cadáver para os embalsamadores, que atuavam nas wabt wat (lugar puro) ou na per nefer (lugar belo), que retiravam o cérebro bem como a evisceração (retirada de órgãos internos). A dessecação do corpo com natrão durava em torno de 40 dias, correspondia às etapas 4 á 7 e era realizada por profissional denominado de ut. Nas fases 12 e 13, a superfície do corpo era tratada com resinas e óleos aromáticos visando amaciar a pele e deixar a tonalidade da pele mais próxima da natural. Finalmente, nas quatro semanas seguintes, o/a defunto/a era envolto/a em linho, momento no qual amuletos protetores eram também colocados (PARRA, 2015).

As práticas 22 e 33 discorreram sobre o uso da mucosidade do Aloe vera (babosa) em aulas de coloração. Parente et al (2013) relatam o uso desta planta no cuidado com a saúde. Ela é descrita no papiro de Ebers, datado de aproximadamente 1550 a.C, no Ta-Meri, na produção de elixires de longa vida. A atividade didática de número 9 discorreu sobre a diafanização, uma etapa da preparação tecidual que torna o material biológico translúcido e macio, e que corresponderia às fases 12 e 13 do processo de mumificação.

\footnotetext{
18 As pessoas que não eram da realeza eram levadas para o ibu en hab, o local da purificação, enquanto nobres eram transportados/as para a seh-netjer, a cabine divina (PARRA, 2015, p. 349).
} 
As inovações na didática foram articular os procedimentos de mumificação e também os da diafanização com os processos celulares, de cunho osmótico, ao longo dos quais se verifica grande perda de água. A simplicidade desta atividade permite que ela seja desenvolvida sem a necessidade de um laboratório, pois as aferições do peso podem ser realizadas com balanças domésticas. Inovamos ainda ao propormos procedimentos de coloração a partir da babosidade da Aloe vera, pois seu uso dispensa a utilização de lâminas permanentes, que podem ser de difícil acesso.

\section{CONSIDERAÇÕES FINAIS}

Neste manuscrito, expomos como a Citologia pode contribuir para as discussões relativas à Lei no $10.639 / 2003$. Um aspecto fundamental para o sucesso das atividades foi a apresentação deste marco legal, bem como de alguns de seus desdobramentos, em exposições dialogadas ocorridas nos primeiros dias dos semestres letivos de 2017-1, 2017-2, 2018-1 e 2018-2. Estas foram fundamentais para a ressignificação do 13 de maio, bem como para a introdução do 20 de novembro para os grupos de estudantes, permitindo que no futuro desenvolvam atividades referentes a estas datas a partir de seu campo de formação. A conexão realizada recupera as origens inovadoras da Biologia assim como, permite uma releitura de temas que são específicos dentro do campo da citologia, o que possibilita uma renovação e construção de um processo de ensino/aprendizagem decolonial e inclusivo.

O processo saúde/doença é um dos temas das coleções didáticas trabalhadas ao longo dos ensinos fundamental e médio, porém, nestes dois períodos a base celular das morbidades bem como suas prevalências, no tocante a gente negra, não são apresentadas, por conseguinte, aqui recuperamos a centralidade da célula e de seus constituintes no processo de adoecimento, assim como a base celular de doenças e em particular daquelas que são prevalentes deste grupo populacional. 
A partir dos temas aqui discutidos surgem novas indagações: que novos saberes decolonias poderão emergir do campo, em particular da citologia, bem como, num contexto mais amplo, da própria Biologia? Que outras personalidaes negras serão relembradas? Quais outras estratégias de ensino/aprendizagem poderão fomentar novas contribuições? Que outros saberes diaspórios os/as discentes poderão elaborar a partir desta primeira experiência? Estes novos saberes contribuirão para a transformação de um mundo já conhecido e trarão para o campo da visibilidade uma invisibilidade, a qual foi epistemologicamente construída.

\section{REFERÊNCIAS}

ALVES, M. V. História da medicina em Portugal. Origens, ligações e contextos. Porto: Porto Editora, 2014.

AMENDOLA, L. C. B.; VIEIRA, R. A contribuição dos genes BRCA na predisposição hereditária ao câncer de mama. Revista Brasileira de Cancerologia, v. 51, n. 4, p. 325-330, 2005.

AMODEO, C.; HEIMANN, J. J. C. Revisão/atualização em hipertensão arterial: o fenômeno da sensibilidade ao sal. Jornal brasileiro de nefrologia, v. 20, n. 1 , 68-73, 1998.

ANASTASIOU, L. G. C.; ALVES, L. P. Estratégias de ensinagem. In: ANASTASIOU, L. G. C.; ALVES, L. P. (Orgs.). Processos de ensinagem na universidade. Pressupostos para as estratégias de trabalho em aula. 3. ed. Joinville: Univille, 2004. p. 67-100.

ARAÚJO, L. M. O Egito faraónico. Uma civilização com três mil anos. Lisboa: Arranha-céus, 2015.

ARAÚJO, M.; MAESO, S. R. A presença ausente do racial: discursos políticos e pedagógicos sobre história, "Portugal" e (pós-)colonialismo. Educar em revista, n. 47, p. 145-171, 2013.

ARAÚJO, M.; MAESO, S. R. Os contornos do eurocentrismo. Raça, história e textos políticos. Coimbra: Almedina/CES, 2016.

BENITE, A. M. C.; SILVA, J. P.; ALVINO, A. C. Ferro, ferreiros e forja: o ensino de química pela Lei $N^{\circ}$ 10.639/03. Educação em Foco, Juiz de Fora, v. 21, n. 3 , 735-768, set. / dez. 2016.

BOTELHO, D.; MARQUES, F. Diversidade: raça, gênero, desvios e desafios nas escolas. In: NUNES, M. L. S.; MACHADO, C. J. S.; VASCONCELOS, L. M. (Orgs.) Diálogos sobre gênero, cultura e história. Fortaleza: UECE, 2015, v. 1, p. 29-52.

BOMFIM, M. A América Latina: males de origem. Centro Edelstein de Pesquisas Sociais. Rio de Janeiro, 2008. 
BRASIL, MEC/SECAD. Orientações e Ações para a Educação das Relações Étnico-Raciais. Brasília: SECAD, 2006.

BRASIL. Ministério da Educação/Secad. Diretrizes curriculares nacionais para a educação das relações étnico-raciais e para o ensino de história e cultura afro-brasileira e africana na educação básica. Brasília, 2004.

BRASIL. Ministério da Saúde. Secretaria de Políticas de Saúde. Manual de doenças mais importantes, por razões étnicas, na população brasileira afrodescendente. Ministério da Saúde, Secretaria de Políticas de Saúde. Brasília: Ministério da Saúde, 2001 a.

BRASIL. Manual de diagnóstico e tratamento de doença falciformes. Brasília: ANVISA, $2001 \mathrm{~b}$.

BYRNES, W. M.; ECKBERG, W. R. Ernest Everett Just (1883-1941). An early ecological developmental biologist. Developmental Biology, v. 296, n. 1, p. 1$11,2006$.

CANHÃO, T. F. A alimentação no antigo Egipto. Hapi, v. 3, p. 33-89, 2015.

COELHO, M. C.; COELHO, W. N. B. The degree in history teaching and the 10.639/03 statute - training paths to deal with difference?. Educ. rev., $v$. 34, e192224, 2018.

CASTAÑEDA, L. A. História natural e as ideias de geração e herança no Século XVIII: Buffon e Bonnet. História, Ciências, Saúde - Manguinhos, Rio de Janeiro, v. 2, n. 2, 1995, p. 33-50.

CIURANA, E. Pensar os sete saberes necessários - a educação para uma política de civilização planetária. In: MORAES, M. C.; NAVAS, J. M. B. (Orgs.). Complexidade e transdiciplinaridade em educação. Rio de Janeiro: Wak, 2012, p. 83-92.

DE ROBERTIS Jr, E. D. P.; HIB, J.; PONZIO, R. Biologia celular e molecular. Rio de Janeiro: Guanabara Koogan, 2003.

DIOP, C. A. Origem dos antigos egípcios. In: MOKHTAR, G. (Org.). História Geral da África, v. II, Brasília, Unesco/Ministério da Educação, 2010, p. 1-36.

DOMINGUES, P. Movimento negro brasileiro: alguns apontamentos históricos. Tempo, v. 12, n. 23, p. 100-122, 2007.

DUARTE, R. H. A voz mais alta da Biologia. In: DUARTE, R. H. A Biologia militante. 1. Ed. Belo Horizonte: Editora da UFPM, 2010, p. 23-72.

DURAND, O. C.; SOUSA, J.; TIRELLI, P. Experiências educativas da juventude: entre a escola e os grupos culturais. Revista Perspectiva, n. 1, p. 163-182, 2002.

FARIA, J.; GODINHO, C.; RODRIGUES, M. Miomas uterinos, revisão da literatura. Acta Obstétrica e Ginecológica Portuguesa, n. 2, v. 3, p. 131-142, 2008.

FREIRE, P. Pedagogia do oprimido. São Paulo: Editora Paz e Terra, 2005. 
FREIRE, P. Pedagogia da indignação. São Paulo: Editora UNESP, 2000.

FREIRE, P. Cartas à Guiné-Bissau: registros de uma experiência em Processo. Rio de Janeiro: Paz e Terra, 1978.

GASPAR, M. Aquaporinas: de canais de água a transportadores multifuncionais em plantas. Revista Brasileira de botânica, v. 34, n. 4, p. 481$491,2011$.

GARGANTILHA, P. História curiosa da medicina, Porto: Esfera, 2019.

GUPTA, L. Chemokine receptors in HIV infection. International Journal

Pharmacy and Pharmaceutical Sciences, v. 4, p. 69-72, 2012.

GREENIDGE, K. C.; DWECK, M. Glaucoma in the Black Population: A Problem of Blindness. Journal of the National Medical Association, n. 80, v. 12, p. 1305$1309,1988$.

HARRAP, S. B. Where are all the blood-pressure genes? Lancet, v. 361, p. 149$151,2003$.

HENRY, J. P. Stress, salt and hypertension. Social Science \& Medicine, v. 26, n. 3, p. 293-302, 1988.

LEAL, A. M. O.; VOLTARELLI, J. C. Perspectivas da terapia com células-tronco para o diabetes mellitus tipo 2. Revista Brasileira de Hematologia e Hemoterapia, v. 32, n. 4, p. 329-334, 2010.

LOBO, Os infames da história. Pobres, escravos e deficientes no Brasil. Rio de Janeiro, Faperj, 2008.

LOPES, F. Experiências desiguais ao nascer, viver, adoecer e morrer: tópicos em Saúde da População Negra no Brasil. In: LOPES, F. Saúde da População Negra no Brasil: Contribuições para a Promoção da Equidade. Brasília: Funasa, 2005, p. 9-45.

LUCHS, A.; PANTALEÃO, C. Apoptosis and in vivo models to study the molecules related to this phenomenon. Einstein São Paulo, v. 8, n. 4, p. 495497, 2010.

MARCONDES, M. E. R. As Ciências da Natureza nas $1^{a}$ e $2^{a}$ versões da Base Nacional Comum Curricular. Estudos avançados, v. 32, n. 94, p. 269284, dez. 2018.

MARIGO, F. A.; CRONEMBERGER, S.; CALIXTO, N. Neuroproteção: situação atual no glaucoma. Arquivos Brasileiros de Oftalmologia, v. 64, n. 2, p. 167 171, Apr. 2001.

MARSHALL JR, M. C. Diabetes in African Americans. Postgraduate Medical Journal, v. 81, p. 734-740, 2005.

MARTINS, C. Desalinhar abismos no reverso do moderno: perspectivas feministas pós-coloniais para um "pensamento alternativo das alternativas". 
In: SANTOS, B. S.; MARTNS, B. S. O pluriverso dos direitos humanos: a diversidade das lutas pela dignidade. Lisboa: Editora 70, 2019, p. 531-555. MAYR, E. Introdução. Biologia - ciência única. São Paulo: Companhia das Letras, 2005. p. 17-26.

MELLO-LEITÃO, C. F. A vida maravilhosa dos animais. São Paulo: Companhia Nacional, 1935.

MIGNOLO, W. D. Desobediência epistêmica: a opção descolonial e o significado de identidade em política. Cadernos de Letras da UFF, n. 34, p. 287-324, 2008.

MJOEN, J. A. Cruzamento de raças. Boletim de eugenia, n. 19, p. 1-6, 1931. MORAIS, R. F.; SANTOS, A.; Carlos F. A importância de um currículo com elementos afrocentrados para a constituição de uma visão epistemológica menos eurocentrada. Revista Exitus, v. 9, n. 4, p. 66-94, 2019.

MOREIRA, R. C.; VIANA, C. S. Avanços e desafios na implementação da lei 10.639/2003: um estudo na rede municipal de ensino de Senhor do Bonfim/BA. Trilhas Pedagógicas, v. 5, n. 5, p. 150-167, 2015.

MORIN, E. A cabeça bem-feita: repensar a reforma, reformar o pensamento. Rio de Janeiro: Bertrand Brasil, 2003.

NASSEH, I. E. et al. Doenças Mitocondriais. Revista de Neurociências, v. 9, n. 2, p. 60-69, 2001.

NORTE, J. O Brasil e a raça. Boletim de eugenia, n. 8, p. 4. 1929.

OLIVER, G. A mesa do mestre cervejeiro: descobrindo os prazeres das cervejas e das comidas verdadeiras. São Paulo: Editora Senac, 2012.

PARENTE, L. M. L. e† al. Aloe vera: características botânicas, fitoquímicas e terapêuticas. Arte Médica Ampliada, v. 33, n. 4, p. 160-164, 2013.

PARRA, J. M. La vida cotidiana en el antiguo Egipto. Buenos Aires: Editorial El Ateneo, 2015.

PENA, S. D. J.; BORTOLINI, M. C. Pode a genética definir quem deve se beneficiar das cotas universitárias e demais ações afirmativas? Estudos avançados, v. 18, n. 50, p. 31-50, 2004.

POLISELI, I.; OLIVEIRA, E. F.; CHRISTOFFERSEN, M. L. O Arcabouço filosófico da biologia proposto por Ernst Mayr. Revista Brasileira de História da Ciência, $v$. 6, n. 1, p. 106-120, 2013.

PORTOCARRERO, V. As ciências da vida: de Canguilhem a Foucault. Rio de Janeiro: Fiocruz, 2009.

ROCHA, S. P.; SILVA, J. A. N. À luz da lei 10.693/03, avanços e desafios: Movimentos Sociais Negros, Legislação Educacional e Experiências Pedagógicas. Revista da Associação Brasileira de Pesquisadores/as Negros/as (ABPN), [S.I.], v. 5, 11, P. 55-82, out. 2013. 
ROSA, C. A. P. Biologia. In: ROSA, C. A. P. História da Ciência: o pensamento científico e a Ciência no Século XIX. Brasilia: FUNAG, v. 2, †. 2, 2010, p. 232-302. SANTOS, B. S. Para além do pensamento abissal: das linhas globais a uma ecologia de saberes. In: SANTOS, B. S.; MENESES, P. (Orgs.). Epistemologias do Sul. Coimbra: CES/Almedina, 2010, p. 23-72.

SANTOS, B. Para uma sociologia das ausências e para uma sociologia das emergências. Revista Crítica de Ciências Sociais, n. 63, p. 237-280, 2002.

SILVA, J. A. N. Conquista de direitos, ensino de ciências/biologia e a prática da sangria entre os/as remetu-kemi e povos da região congo/angola: uma proposta de articulação para a sala de aula. Revista da Associação

Brasileira de Pesquisadores/as Negros/as (ABPN), v. 9, n. 22, p. 149-175, 2017.

SILVA, J. A. N.; SOARES, K. M. S.; SILVA, C. C. Sexualidade e sexo (in)seguro entre adolescentes e jovens, dos anos finais, de duas escolas públicas de nível fundamental da cidade de João Pessoa/PB(Brasil). Revista Tempos e Espaços em Educação, v. 8, p. 61-76, 2015.

SILVA, J. A. N. A. Lei 10639/2003 e a saúde/mumificação no Antigo Egito: da teoria à prática. In: BRAGA, C. F.; SILVA, J. A. N. A. UFPB na sua escola: a ciência em suas mãos. 1 ed. João Pessoa: CCTA, 2015, p. 47-64.

SILVA, A. S.; PINHEIRO, B. C. S. Químicxs negros e negras do século xx e o racismo institucional nas ciências. Revista Exitus, v. 9, n. 4, p. 121-146, 2019.

VERRANGIA, D.; SILVA, P. B. G. Cidadania, relações étnico-raciais e educação: desafios e potencialidades do ensino de ciências. Educação e Pesquisa, v. 36, n. 3, p. 705-718.

SONATI, M. F.; COSTA, F. F. Genética das doenças hematológicas: as hemoglobinopatias hereditárias. Jornal de Pediatria, v. 8, n. 4, p. S40-S51, 2008.

VERRANGIA, D. Conhecimentos tradicionais de matriz africana e afrobrasileira no ensino de Ciências: um grande desafio. Revista África e Africanidades, n. 8, np, 2010.

Recebido em: 25 de maio de 2020 Aprovado em: 10 de novembro de 2020 Publicado em: 16 de novembro de 2020 